\title{
Pelatihan Membuat ljin Usaha Secara On-Line Di Tengah Pandemi Covid 19, Untuk Usaha Mikro Dan Kecil Di Kelurahan Bambu Apus Cipayung, Jakarta Timur
}

\author{
Dinni Agustin, Robert, Siregar, Mei Supriyani, Nurminingsih \\ Prodi Administrasi Bisnis Fakultas Manajemen dan Bisnis Universitas Respati Indonesia \\ dinniagustin@urindo.ac.id
}

\begin{abstract}
Abstrak
Memiliki Izin Usaha Mikro dan Kecil (IUMK) adalah tanda legalitas atau kepastian hukum bagi pelaku usaha kecil. Akan tetapi pada kenyataanya, banyak para pelaku usaha kecil yang belum mengetahui tentang cara pembuatan Izin Usaha Mikro Kecil (IUMK) dan peruntukannya. Pelatihan ini bertujuan untuk memberi pemahaman kepada pelaku UMKM tentang mudahnya proses pembuatan ijin usaha bagi UMK, karena masih banyak diantara pelaku UMK yang masih belum memiliki ijin, terlebih dalam kondisi seperti sekarang ini, dengan adanya peraturan jarak fisik karena wabah covid-19 maka sulit bagi mereka untuk mengurus ijin atau bahkan bertanya mengenai bagaimana prosedur pembuatan ijin usaha. Oleh karena pelatihan ini dilakukan melalui aplikasi zoom. Hasil dari kegiatan pelatihan adalah antusiasme peserta yang mendaftar melalui zoom sebanyak 281 peserta dengan pertanyaan seputar syarat-syarat untuk mengajukan ijin usaha secara online serta bagaimana mengembangkan usahanya melalui medi online.
\end{abstract}

Kata kunci: ijin usaha online, UMK

\section{Abstract}

Micro and small business licenses, abbreviated as IUMK are a sign of legality or legal certainty to certain business activities in the form of micro and small business licenses, so every business must have a legal permit. In fact, many small businesses do not know how to obtain the permit (IUMK) and its designation. The purpose of this training is to give MSEs an understanding of the ease of the process of making business licenses for MSEs, because there are still many MSEs who do not have a permit yet, especially in current conditions of the outbreak, with the physical distancing regulation due to the pandemic of covid-19, it is difficult for them to get a permit or even ask about the procedure for making a business permit. This training is done through the zoom application. The result of the training activity was the enthusiasm of participants who registered via zoom as many as 281 participants with questions about the requirements for how to applying for a business permit by online application and how to develop their business through online media.

Keywords: online business permit, MSEs

http://ejournal.urindo.ac.id/index.php/PAMAS 


\section{Pendahuluan}

\subsection{Latar belakang}

Pelaku Usaha Mikro Kecil (UMK) memiliki kontribusi besar terhadap Produk Domestik Bruto (PDB) di Indonesia sebesar 60,34\% pada tahun 2017. Selain menjadi penggerak ekonomi di Indonesia, UKM juga menjadi penyerap tenaga kerja yang paling efektif, terbukti serapan tenaga kerja tahun 2017 sebesar 97,22\%, sehingga bisa mengurangi jumlah angka pengangguran yang ada saat ini.

Agar kegiatan usaha berjalan baik, penting untuk memiliki Izin Usaha Mikro dan Kecil (IUMK) sebagai tanda legalitas bagi pelaku usaha dalam menjalankan kegiatan usahanya. Izin usaha berupa satu lembar kertas yang sah dan legal secara hukum yang diterbitkan oleh Lembaga OSS (Online Single Submission) dengan tujuan untuk memberikan kepastian hukum dan sarana pemberdayaan bagi pelaku usaha mikro dan kecil dalam mengembangkan usahanya.

Saat ini mengurus IUMK bisa dengan mudah dan cepat, yaitu satu hari sudah bisa selesai asal semua berkas persyaratan sudah dipenuhi, akan tetapi dalam kenyataanya, banyak para pelaku usaha kecil yang belum memiliki dan mengetahui tentang Izin Usaha Mikro Kecil (IUMK) dan peruntukannya.

Walaupun pemerintah telah mempermudah proses pembuatan ijin usaha bagi UMK, akan tetapi banyak diantara pelaku UMK yang masih belum memiliki ijin, terlebih dalam kondisi seperti sekarang ini, dengan adanya peraturan PSBB sulit bagi mereka untuk mengurus ijin atau bahkan bertanya mengenai bagaimana prosedur pembuatan ijin usaha.

Berdasarkan permasalahan tersebut maka kami merasa perlu dan penting untuk membantu para pelaku UMK dalam membuat ijin usaha ditengah pandemi covid 19 dengan cara memberikan pelatihan secara online menggunakan aplikasi zoom dari smart phone atau komputer mereka sehingga memudahkan pelaku UMK dalam mempelajari dan menyiapkan dokumen yang diperlukan untuk proses pembuatan ijin usaha. 


\subsection{TUJUAN}

Pelatihan ini bertujuan untuk memberikan informasi dan cara-cara membuat ijin usaha secara online bagi pelaku UMKM di tengah pandemi covid-19, kepada pelaku UMKM di wilayah Kelurahan Bambu Apus, Jakarkta Timur.

\section{METODE}

Sasaran kegiatan ini pada awalnya adalah 25 orang pelaku UMKM di Kelurahan Bambu Apus, Cipayung, Jakarta Timur, akan tetapi karena wabah covid-19 dimana diberlakukan jarak fisik maka kegiatan pelatihan dilakukan secara on-line melalui aplikasi zoom. Diharapkan setelah program ini maka upaya pembuatan ijin usaha sudah bisa dilaksanakan dengan baik oleh pelaku UMKM.

Pelatihan online selain diisi dengan paparan materi pelatihan untuk pembutan ijin usaha secra online, juga dilakukan diskusi dan tanya jawab, demonstrasi, dan tutorial kepada peserta pelatihan dalam upaya mempermudah menyiapkan ijin usaha.

\subsection{Tahapan persiapan}

Semua data yang ada berdasarkan data identifikasi pada saat awal pelaksanaan program pengabdian ini setelah disetujui untuk dilaksanakan. Untuk mendukung efektifitas program pengabdian kepada masyarakat maka diajukan kerangka pemecahan masalah yang meliputi:

1. Tim pengabdi harus memiliki kompetensi teoritis dan praktis yang memadai dalam pelatihan pembuatan ijin usaha.

2. Persiapan pelaksanaan harus dilakukan secara menyeluruh, mulai dari menyiapkan dokumen perijinan sampai evaluasi dengan melibatkan pihak-pihak yang bertanggungjawab seperti Pihak Pemerintah dalam hal ini Kelurahan.

3. Materi pelatihan akan dilaksanakan secara online berupa pemberian informasi mengenai ijin usaha secara keseluruhan berupa tahap-tahap pengajuan ijin secara online, serta dokumen-dokumen yang harus dipersiapkan oleh pelaku UMK melalui webinar. 
4. Evaluasi program akan dilaksanakan secara menyeluruh, meliputi: persiapan kegiatan, pelaksanaan, materi yang disampaikan, pelatih, peserta dan penyelenggaraan serta akhir kegiatan.

5. Output yang dapat dibuat oleh peserta pelatihan berupa dokumen yang sudah siap diajukan untuk menerbitkan ijin usaha.

\subsection{Waktu dan tempat pelaksanaan}

Webinar dilaksanakan pada hari Sabtu, 27 Juni 2020, pukul 10.00-12.30 WIB. Peserta yang ditargetkan akan mengikuti pelatihan adalah sebanyak 200 orang peserta.

Tempat pelaksanaan webinar bagi narasumber dilaksanakan di kampus Universitas Respati Indonesia dengan tetap memberlakukan jarak fisik, sedangkan bagi peserta mengikuti dari tempat masing-masing.

\subsection{Tahapan Pelaporan}

Pelaporan dari kegiatan Pengabdian kepada Masyarakat akan dilaksanakan pada akhir kegiatan agar dapat merangkum hasil serta membuat rencana tindak lanjut sebagai hasil pelatihan.

\section{HASIL KEGIATAN}

Sebagai kegiatan akhir dari pengabdian masyarakat "Pelatihan Membuat ljin Usaha secara Online bagi Usaha Mikro Kecil dan Menengah di Kelurahan Bambu Apus Jakarta Timur", dan untuk mensiasati terjadinya wabah covid-19, dimana masyarakat dilarang berkumpul (physical distancing), maka kegiatan dilakukan secara on-line melalui aplikasi zoom.

Webinar telah diselenggarakan pada hari Sabtu, 27 Juni 2020 pukul 10.00-12.30 WIB, yang diikuti sebanyak 281 orang peserta dari target 200 orang peserta. 


\subsection{Karakteristik peserta pelatihan}

Sesuai dengan informasi awal yang diperoleh dari Kelurahan Bambu Apus, diketahui bahwa tingkat pendidikan seluruh peserta pelatihan adalah berasal tingkat pendidikan SD dan SMP, dengan adanya perbedaan latar pendidikan tersebut, menyebabkan adanya perbedaan pemahaman materi yang disampaikan, terlihat dari pertanyaan-pertanyaan yang diajukan pada saat diskusi tanya jawab.

\subsection{Respon dari peserta pelatihan}

Berdasarkan pengamatan dari materi ijin usaha, pemasaran serta model bisnis canvas yang dibarengi dengan simulasi dan diskusi selama selama pelatihan berlangsung, diketahui bahwa respon peserta terhadap keseluruhan materi yang disampaikan cukup baik. Melihat hasil evaluasi sebelum dan setelah penyampaian materi, terlihat bahwa respon peserta cukup baik, hal ini ditandai dengan adanya antusiasme peserta dalam mengajukan pertanyaan dalam setiap sesi tanya jawab dan diskusi.

\subsection{Solusi yang ditawarkan}

Penyelenggaraan kegiatan pengabdian kepada masyarakat ini merupakan langkah awal dalam mendukung pengembangan potensi pelaku usaha kreatif yang ada di Kelurahan Bambu Apus dengan melengkapi usahanya dengan legalitas ijin usaha yang dapat diajukan secara online. Tindak lanjut kegiatan terkait dengan permasalahan yang ada, maka solusi yang kami coba tawarkan adalah sebagai berikut:

1. Identifikasi sasaran, yaitu pelaku UMKM (Usaha Mikro Kecil dan Menengah) diwilayah Kelurahan Bambu Apus, Cipayung, Jakarta Timur yang belum memiliki ijin usaha. Dengan kegiatan ini maka data yang didapatkan akan lebih akurat mulai dari pelaksanaan program pengajuan ijin usaha online, evaluasi sampai dengan keberlanjutannya

2. Edukasi pelaku UMKM. Kegiatan dalam bentuk seminar disarankan untuk dilaksanakan selepas wabah covid-19, dengan melibatkan semua unsur dalam pelaksanaan program, diharapkan terjadi peningkatan pengetahuan, perbaikan sikap dan perilaku yang akan diukur sebelum maupun setelah pelaksanaan kegiatan.

3. Pemberian Pelatihan kepada pelaku UMKM, dalam hal ini yang telah dilaksanakan 
melalui webinar dengan aplikasi zoom, diharapkan dapat meningkatkan pengetahuan pelaku UMKM, sehingga mereka dapat praktek mengajukan ijin usaha secara online, sesuai dengan tahap-tahap yang diberikan pada pelatihan. Bila diperlukan pelatihan dapat dilakukan ulang, sesuai kebutuhan dengan difasilitasi oleh Kelurahan Bambu Apus, Jakarta Timur.

\section{Simpulan}

Pelaksanaan kegiatan pengabdian kepada masyarakat di Kelurahan Bambu Apus, oleh Program Studi Administrasi Bisnis Fakultas Manajemen dan Bisnis Universitas Respati Indonesia sangat memberi dampak positif bagi pembinaan dan perkembangan pelaku usaha kecil dan menengah di wilayah Kelurahan Bambu Apus, Jakarta Timur, khususnya terkait upaya mendapatkan ijin usaha.

Kesimpulan berdasarkan hasil pelaksanaan pengabdian masyarakat adalah:

1) Kegiatan Pengabdian kepada Masyarakat ini merupakan salah satu upaya dosen dan mahasiswa guna mengembangkan potensi diri serta pengabdian pada masyarakat dalam hal ini pelaku UMKM dan dapat berperan dalam membantu memperoleh ijin usaha mereka.

2) Peran pemerintah setempat dalam hal ini pihak kelurahan sangat diperlukan sekali sebagai pihak yang membina pengembangan pelaku usaha kecil dan menengah di daerah dalam meningkatkan ekonomi kreatif.

Dengan memiliki ijin usaha yang merupakan syarat legal dalam dunia usaha, maka para pelaku usaha akan semakin mudah mendapatkan investor dalam memberikan bantuan modal usaha, serta mempermudah memasarkan produk yang dihasilkan.

\section{DAFTAR PUSTAKA}

Peraturan Presiden Republik Indonesia Nomor 98 Tahun 2014

Deandra Syarizka, 'Kontribusi UMKM terhadap PDB 2019 Diproyeksi Tumbuh 5\%' (Bisnis.com, 9 Januari 2019) <https://ekonomi.bisnis.com/read/ 20190109/12/876943/kontribusiumkm-terhadap-pdb-2019-diproyeksi-tumb uh-5> diakses pada 19 Oktober 2019. 
Jurnal Pelayanan dan Pengabdian Masyarakat (PAMAS)

Dyah Ikhsanti, '4 Manfaat Utama Jika Usaha Anda Memiliki Surat Izin yang Sah' (Atur Duit, 6 Maret 2019) <https://www.aturduit.com/articles/manfaat-punya-izin usaha> diakses pada 19 Oktober 2019.

Eril Obeit Choiri, 'Pentingnya Memiliki Izin Usaha Mikro Kecil (IUMK) di Indonesia' (Jurnal by Mekari, 7 April 2018) <https://www.jurnal.id/id/blog/2018

pentingnya-memiliki-izin-usaha-mikro-kecil-iumk-bagi-umkm-di-indonesia> diakses pada 19 Oktober 2019.

Muhammad Zainul Arifin, Understanding The Role Of Village Development Agency In Decision Making, Kader Bangsa Law Review,

http://ojs.ukb.ac.id/index.php/klbr, https://scholar.google.co.id/citations?use

r=SFDX82UAAAAJ\&hl=id, https://unsri.academia.edu/MuhammadZainul

Arifin, https://www.researchgate.net/profile/Muhammad_Arifin

Undang-Undang Republik Indonesia Nomor 20 Tahun 2008 tentang Usaha Mikro, Kecil, dan Menengah (UMKM).

http://ejournal.urindo.ac.id/index.php/PAMAS 